\title{
Grija pastorală în Sfintele Taine, între misiunea Bisericii și provocările contemporane ale ecumenismului
}

\section{Paul Octavian PORCESCU}

\begin{abstract}
The Church's mission today is no longer conceivable only in the generous context of ecumenical dialogue, be it parish level, either by the diocese or the Church. The Ecumenism of Church's mission is a greater chance since recapitulates the beginnings of the Christian Church. Analytical relationship between pastoral activity like mission and the Sacraments as a means of pastoral care is like a constant of this paper. A paper that includes a bidirectional approach to research: a). Syntheticanalytical delineation of the main considerations in systematically register, referentials at theological level, on the sacramental-liturgical pastoral care of the present, and b). a summative foray into observing and anticipating the main challenges of the contemporary world on the mission of the parish and the Church in the context of parish pastoral work through the Sacraments. The overall findings converge to provide an answer to the dilemma induced by the double registry of the study purpose, set by the title.
\end{abstract}

Keywords: Sacraments, Pastoral Care, Ecumenism, Mission of the Church, Parish, Sacramental Theology, Pastoral Theology 


\section{Preliminarii. Pastorația - efect al slujirii lui Hristos și condiție a ecumenismului}

Textele Noului Testament, mai ales cele din Evanghelii, Faptele Apostolilor şi din epistolele pastorale, precum şi din literatura bisericească, ne înfăţisează pe preot ca pe o călăuză sau îndrumător al credincioşilor pe calea spre mântuire. Apostolatul este o slujire a lui Dumnezeu şi a oamenilor, în acelaşi timp. „Preotul slujeşte pe Hristos slujind pe semenii săi, luminându-i, călăuzindu-i pe calea cea dreaptă şi ajutându-i din toate puterile sale în strădania lor spre lumină şi fericir, spre mântuire. Acesta este sensul preoţiei ortodoxe: slujirea lui Dumnezeu şi a poporului"”.

Slujirea, în îndoitul ei aspect a fost specificul creştinismului chiar de la începuturile lui; dar în contextul lumii de astăzi şi al societătii, ea nu presupune renunţarea la tradiţia Bisericii, ci se înscrie pe linia acestei tradiţii. Apostolatul, misiunea preotului este expresia slujirii deopotrivă a lui Dumnezeu şi a oamenilor, a Bisericii şi a poporului căruia aceasta aparţine prin credincioşii ei. Căci dacă Biserica se preocupă de raportul cu lumea în general, cu atât mai mult trebuie să se preocupe de raportul cu poporul în mijlocul căruia ea lucrează. Membrii Bisericii înţeleg lumea în dimensiunile ei concrete, istorice. Însă apostolatul, prin forma lui concretă, denumit ca şi apostolat social, ca doctrină şi formă de slujire constituie forma de pastoraţie deosebit de eficace. ${ }^{2}$ Cele două forme cunoscute de pastoraţie, individuală şi colectivă, se desfăşoară simultan, pe două planuri: local, la nivelul relaţiilor $e u$-tu, la nivelul parohiei şi al Bisericii locale, naţionale şi universale, la nivelul marilor regiuni sau la nivel mondial. Prezenţa Bisericii în lume prin slujire, pastoraţie, atât pe plan local cât şi pe plan universal, este un imperativ al mesajului primit de ea de la

\footnotetext{
${ }^{1}$ Patriarhul Justinian, Apostolat social, vol. V, 1948, p. 20.

${ }^{2}$ Episcop Dr. Antonie Plămădeală, Biserica slujitoare, Bucureşti, 1972, pp. 283-284.
} 
Hristos, capul ei, prin Sfinţii Apostoli (Matei XXVIII, 19-20; Marcu XVI, 15-16) şi al lucrării ei spre mântuirea tuturor (Matei XX, 28; Marcu X, 45). Pastoraţia, slujirea se face în numele lui Hristos şi de aici stilul ei propriu: flexibil şi în funcție de nevoile concrete ale momentului cu care este confruntat poporul, fiecare creştin în parte. Şi fiindcă Hristos se identifică pe Sine cu semenul aflat în nevoie şi care aşteaptă mântuirea, pastoraţia, indiferent de formele ei, este o slujire a lui Hristos Însuşi ${ }^{3}$.

De la început, misiunea Bisericii a fost bidirecțională: misiunea ad intra, sau internă (Biserica s-a ocupat de cei botezați, organizând viața internă, liturgică, socială) și misiunea ad extra, externă (Biserica a propovăduit și mărturisit Evanghelia celor din afară - Fapte 11, 3). Astfel, Biserica apare atât ca o comunitate euharistică - poporul lui Dumnezeu deja răscumpărat, care se adună să comemoreze faptele lui Dumnezeu din istoria mântuirii, trăind o viață nouă în Duhul Sfant - cât și ca o comunitate apostolică misionară, care are conștiința unei trimiteri speciale către cei necredincioși. Așadar, Biserica dispune de două piloane esențiale cu care actualizează iconomia mântuirii: cel pastoral, având disciplina ei internă, euharistică, și cel misionar, având proiectul ei apostolic, de a răspândi Evanghelia.

Pastoraţia creştină în îndoitul ei aspect, individual şi colectiv, este, în fond o teologie a aproapelui, cerută astăzi mai mult ca oricând. „Dumnezeu care a creat pe toţi are grijă de toţi. El ne cheamă însă şi pe noi să avem grijă de copiii Săi, să avem grijă unii de alţii. Ne cheamă să-i fim colaboratori în această grijă a Lui de noi înşine şi de semenii noştri. Toată osteneala în zidirea reciprocă este colaborare a noastră cu Dumnezeu (I Corinteni III, 8-9). Dumnezeu vrea, în definitv, să creştem în iubirea noastră intreolaltă. Prin aceasta răspundem solicitării Lui sau împlinim voia Lui. Dar fără efortul nostru, fără străduinţa noastră într-o slujire reciprocă, fără trăirea intr-o efectivă răspundere reciprocă, nu ne achităm de răspunderea

${ }^{3}$ Ibidem, p. 305 
faţă de Dumnezeu”. „Biserica Ortodoxă - notează pr. Dumitru Stăniloae - socoteşte că mântuirea nu se finalizează în moartea lui Hristos pe cruce, ca echivalent juridic al jignirii ce a adus omenirea lui Dumnezeu, ci în unirea lui Hristos cel răstignit şi înviat cu oamenii ce cred în El, pentru ca şi ei să poată muri păcatului şi învia. Consecvent cu aceasta, ea acordă Tainelor un loc de mare importanţă in iconomia mântuirii ca mijloace prin care se înfăptuieşte această unire a oamenilor cu Hristos",

\section{„Ecumenismul sacramental” sau pastorația prin Sfintele Taine „ca toți să fie Una”}

Valoarea intrinsecă a Sfintelor Tainelor este una hristologică, pnevmatologică şi bisericească, nicidecum una confesională. Așa cum afirma Hristou Andrutsos, noi nu ne putem priva de Sfintele Taine decât în favoarea nesfinţirii şi, în final, a despărţirii de Hristos. „Înstrăinarea de sfinţenie este înstrăinarea de fundamentul Sfintelor Taine, este instrăinarea de inţelesul autentic al lor"'.

Ecumenismul sacramental nu se poate justifica în logica motivelor pentru care creştinismul s-a fărâmiţat, fragmentat multipolar. Nu negăm existenţa motivelor teologice la baza schismei, a reformei şi a celorlalte despărţiri confesionale, dar în realitate cele morale, politice, etnice au stat la baza acestei fragmentări. La fel, nu poate fi negat faptul că realitatea unei anumite sensibilități a ecumenismului sacramental este dezvoltată dintr-o confuzie între sentimentul de apartenenţă la o confesiune creştină cu sentimentul de apartenenţă la Hristos. Tainele sunt mijloace ale harului dumnezeiesc care ne

\footnotetext{
${ }^{4}$ Pr. Prof. Dr. D. Stăniloae, Slujitori ai lui Dumnezeu, slujitori ai oamenilor, în rev. „Biserica Ortodoxă Română”, anul LXXXVIII (1970), nr. 3-4, pp. 413-414 ${ }^{5}$ Idem, Teologia dogmatică ortodoxă, vol. 3, p. 7.

${ }^{6}$ Hristou Andrutsos, Simbolica, p. 239.
} 
legitimează să aparţinem trupului lui Hristos şi derivă din Acesta. $\mathrm{Cu}$ fiecare Taină pe care o primim, Hristos Domnul moare şi învie cu noi, toată existenţa creştină de la Botez şi până la învierea de obşte este determinată de comuniunea în moartea şi învierea cu Hristos. ${ }^{7}$ Tainele sunt respirația continuă a Bisericii prin care ea inspiră şi revarsă neîncetat pe Duhul Sfânt asupra mădularelor ei. Prin Sfintele Tainele şi mai cu seamă prin Euharistie, cu care simţim nevoia să ne împărtăşim cât mai des, dar cu vrednicie, creştem în Hristos până la vârsta deplinătăţii Sale (Efes. 4, 13). De aici şi importanța hotărâtoare pe care Sfintele Taine de iniţiere o au în soteriologie, care este una prin excelență ecumenică, întrucât Hristos a afirmat: „Mă rog ca toţi să fie una, cum Tu, Tată, eşti în Mine, şi Eu în Tine, ca şi ei să fie una în noi, pentru ca lumea să creadă că $\mathbf{T} \boldsymbol{u}$ M-ai trimis"(Ioan 17, 21).

Divergenţele și toate diferendele ecumenice din arealul teologiei doctrinare cu referire la Sfintele Taine derivă şi din rolul pe care dimensiunea practică a Sfintelor Taine o incumbă la nivelul pastorației. Astfel, nu poate fi negat faptul că unicitatea naturii Tainelor trebuie discutată separat de unicitatea bisericii, adică de pretenţiile ridicate cu privire la faptul că o anumită biserică este singura a lui Hristos. Dacă există Biserică văzută şi Biserică nevăzută, Biserică locală şi Biserică universală etc. rezultă cu necesitate că toți credincioșii din biserica nevăzută sau universală au comuniune cu Hristos în Tainele ce se săvârşesc în Biserici văzute despre care credem în mod reciproc că sunt greşite. Totuşi, crezul nostru ne obligă la logica inversă a raţiunii folosite anterior: observația că Sfintele taine au un Unic instituitor, derivă de la unicitatea persoanei lui Hristos, ca dar al Unicului tată ceresc, prin unicul Duh Sfânt al Său. Natura Tainelor este una unică. Tainele nu pot fi împărţite, ele sunt a celor care le au. Botezul, Sfânta Euharistie şi toate celelalte trebuie văzute în unicitatea lor. Natura

\footnotetext{
${ }^{7}$ Pr. Ilie Moldovan, Pregătirea morală pentru primirea Sfintelor Taine, în rev. „Glasul Bisericii”, anul XXXVII (1978), nr. 3-4, p. 236
} 


\section{Paul Octavian PORCESCU}

unică a Tainelor ne pune împreună într-un mod unic, într-un mod unic nu ca biserică confesională, ci ca Biserică universală a lui Hristos şi cu Hristos. Iată cum explică Yannaras acest lucru: „, ... Trupul nu este numai carnea omului, ci este întregul complex de relaţii care duc la conservarea şi supraviețirea sa şi la satisfacerea numeroaselor sale nevoi. Viaţa şi adevărul Bisericii sunt toate aceste relaţii transformate in Euharistie şi comuniune iubitoare".

Fondul ecumenic al Tainelor nu trebuie să fie socotit ca o indulgenţă teologică, deşi este de dorit atitudinea conciliantă a teologiei postmoderne. $\mathrm{Nu}$ amabilitatea teologică şi nici intenţiile ecumenice ale bisericilor, nu ele sunt cele care pot, mai devreme sau mai târziu, să ofere un punct comun important în a putea să vedem ce ne uneşte şi ce ne desparte cu privire la Sfintele Taine. Natura Tainelor este intrinsec una ecumenică şi universală, iar acest ecumenism îl realizează participarea intrinsecă a Sfintei Treimi la fiecare Taină. Natura ecumenică a Tainelor este Sfânta Treime. ,.... Inainte de a considera în taine remediul suprem al nevoilor noastre, vedem în ele epifania, arătarea lui Dumnezeu şi efuziunea energiilor indumnezeitoare"9. Prezenţa reală a lui Hristos le conferă nota comună şi tot această prezenţă le face universale. Tainele nu au un conţinut ecumenic şi universal pentru că vrem, ci ele au acest conţinut pentru că sunt teocentrice, hristocentrice, pnevmatocentrice. Nici o Biserică nu poate oficia Sfânta Euharistie, Botezul sau oricare altă Sfântă Taină în afara prezenţei Sfintei Treimi: „Hristos şi Sfânta Treime - subliniază Părintele Stăniloae - nu se cunosc decât prin Biserică în eficienţa Lor, dar pe de altă parte, sunt cunoscuţi ca Taine, pentru că sunt cunoscuţi în realitatea sensibilă a Bisericii"'10. Sau, cum arată prof. Ştefan Buchiu ,în Sfintele Taine, credinciosul se întâlneşte nu numai cu Hristos, Care îl sfinţeşte prin harul Său,

\footnotetext{
${ }^{8}$ Christos Yannaras, Abecedar al credinţei, p. 179.

${ }^{9}$ Paul Evdokimov, Prezenţa Duhului Sfânt în Tradiţia Ortodoxă, p. 117.

${ }^{10}$ Pr. Prof. Dr. Dumitru Stăniloae, Teologia dogmatică ortodoxă, vol. 3, p. 12.
} 
ci şi cu Duhul Sfânt, Cel ce este nedespărţit de Hristos atât în Sfânta Treime, cât şi în Biserică. Lucrarea Duhului Sfânt se impleteşte cu lucrarea lui Hristos în Sfintele Taine, căci harul este unic şi îi unifică pe cei ce-l primesc" "11.

Iar Taina Treimii, ca mod de manifestare a iubirii depline, dezvăluită nouă oamenilor la nivel practic prin efectele Sfintelor Taine, nu prinde contur decât prin ceea ce fiecare Biserică realizează pentru credincioșii pe care îi are: o pastorație care nu poate exclude sâvârșirea Sfintelor Taine. Iar lucrul acesta de datorează faptului că Hristos - Arhiereul Veşnic este Cel care a instituit mijloacele prin care să-şi pună la dispoziție, ca „hrană spre veșnicie”, Trupul pentru noi şi tot El a făcut ca prin această devenire teandrică să fie posibilă lucrarea harurilor Sale în credincioşii care mărturisesc credinţa în El şi care participă nemijlocit la Tainele Sale, adică la realitatea bisericească ce anticipă spaţiul doxologic etern (,,până la sfârșitul veacurilor”), unic (,,ca toți să fie Una”) și nebiruit (,,porțile Iadului nu o vor birui”). Observăm că Sfintele Tainele sunt premisa unei unități de comuniune cu Dumnezeu. Ele unifică prin Hristos pe toţi oameni care participă la săvârşirea lor, atât la nivelul bisericii locale cât şi la nivelul bisericii universale. Existența Tainelor, prin pastorația realizată la nivelul fiecărei Biserici, fiecărei comunități de creștini, face imposibilă păstrarea unei unităţi doar pe criterii confesional creştine, deoarece în ele Trupul lui Hristos, care este unul şi neîmpărţit, harul şi dragostea desăvârșesc.

\section{Misiunea pastorală și pastorația sacramental-misionară în fața provocărilor contemporane}

Misiunea pastorală și pastorația sacramental-misionară a Bisericii şi implicarea ei în dialogurile interconfesionale şi

${ }^{11}$ Ştefan Buchiu, Intrupare şi unitate, p. 175. 
interreligioase constituie un imperativ major al vremurilor prezente, vremuri de transformări ireversibile și cu impact imens la nivel mondial şi naţional: globalizarea ${ }^{12}$ sub toate aspectele ei economice, sociale, culturale şi chiar spirituale. Biserica este misionară în fiinţa ei şi această trăsătură se regăseşte în cea de-a patra notă caracteristică: apostolicitatea $^{13}$.

Între misiunea și concretizarea pastorală a ei din Apus şi Răsărit, de-a lungul istoriei, diferenţa este foarte clară. Apusenii (catolici şi protestanţi) văd extinderea Bisericii orbis terrae, iar Ortodoxia vede misiunea împlinită prin extensiunea lui Hristos Cel mort, înviat şi preaslăvit în cei care cred. Însă doar în spaţiu eclesial Sfintele Taine conferă tensiune şi impun exigenţa pastoral-misionară. Tainele fortifică misionar, îi nasc, cresc şi hrănesc pe oameni. Biserica este un teren de angajament unde se trăiesc intens forţele tensiunilor haric-misionare, unde se pot observa opţiunile divergente, în acelaşi câmp misionar a ordinii ideologice şi sociale, un real pluralism existent într-o manieră de a reprezenta Biserica ${ }^{14}$. Demersul pastoralmisionar al Bisericii prin împărtășirea harului Sfintelor Taine trebuie

${ }^{12}$ Prin caracterul ei universalist, globalizarea tinde la unificarea şi relativizarea valorilor şi identităţilor naţionale, existând pericolul omogenizării. Totodată, acest fenomen particularizează, favorizând individualismul şi pluralismul, printr-o explozie de credinţe şi denominaţiuni religioase. Procesul globalizării implică în sine pericolul sincretismului. Este important ca sincretismul să nu fie înţeles numai în accepţiunea sa negativă, ca o trădare a Ortodoxiei.

${ }^{13}$ Aşadar, o eclesialitate fără apostolicitate, şi invers, nu poate exista. Cele două învăţături fundamentale se intercondiţionează: pe de o parte, Biserica este extensiunea Lui Hristos - Cel mort şi înviat - şi prin El, a întregii Sfintei Treimi, în toţi cei care stau în legătură şi-L mărturisesc drept Cap al Bisericii, împărtăşindu-se de harul Său prin Sfintele Taine ca lucrări văzute şi săvârşite de ierarhia aflată în succesiunea apostolică.

${ }^{14}$ Acest pluralism deschide perspectiva câmpului de tensiuni în care apar noi forme de angajament creştin în urma activităţii misionare, omul contemporan confruntându-se permanent cu evoluţia tehnologic-informaţională şi cu duhul secularizării lumii moderne. 
Pastoral care through the Sacraments...

să cuprindă conceptul potrivit căruia Biserica nu este în fond, doar comunitatea cu extinsă de membri, ci chiar şi cea cu număr mai mic, dar în care sălăşluieşte mărturia cea duhovnicească despre trăirea în viaţa noastră a vieţii lui Iisus Hristos, cea autentică. Astfel înţelese, misiunea și pastorația sacramentale nu este reprezentată de un proiect grandios, asemeni unei caracatiţe care cuprinde totul în sine acesta este de dorit numai pentru a conferi unitate de plan şi acţiune sistemului - ci de intervenţia în micro, de îndeplinirea misiunii de păstor de suflete şi a aceleia de următor al Mântuitorului, calitate pe care o are orice creştin botezat, nu numai clericul şi nu numai cei cu anumite răspunderi în Biserică.

O provocare concretă a Bisericii din contemporaneitate, cu implicații asupra pastorației sacramentale, o constituie migrația - care favorizează transformarea postmodernistă a societății, prin ambele variante ale sale: 1 . din țări sărace, în țări bogate și 2 . din mediul rural, în mediul urban. În ceea ce-i privește pe românii plecați în străinătate, trebuie subliniat faptul că mediul în care trăiesc aceștia este, de cele mai multe ori, neprielnic exprimării apartenenței lor la Ortodoxie. De aceea, „Ortodoxia în Occident rămâne o prezență discretă, care încearcă să explice mai bine lumii occidentale unele aspecte ale spiritualității sale: icoana, rugăciunea lui Iisus, liturghia bizantină "'s. Este imperios necesar să se asigure asistența religioasă cât mai diversificată în diaspora; de aceea, este lăudabilă inițiativa Sf. Sinod al B.O.R. de a spori numărul eparhiilor și parohiilor românești peste hotare. În caz contrar, singura modalitate de a păstra legătura migranților cu tradiția și spiritualitatea românească rămâne Internetul, cu toate capcanele lui. Din fericire, structurile ecclesiale aparținând B.O.R., situate în afara granițelor țării, se bucură de recunoașterea

\footnotetext{
${ }^{15}$ Pr. prof. dr. Emanoil Băbuş, Ortodoxia naţiunilor în Europa Occidentală, în vol. „Biserica Ortodoxă în Uniunea Europeană. Contribuţii necesare la securitatea şi stabilitatea europeană”, Editura Universităţii din București, 2006, p. 113
} 
necesară, precum și de drepturile ce li se cuvin ${ }^{16}$.

\section{Concluzii}

Teologia pastorală a Sfintelor Taine, dar mai exact cultul în acțiune al acestei teologii, prin pastorație, trebuie să fie şi să rămână primită de la Domnul. Prin ea păstrăm deschisă calea harului, adică a energiilor necreate, prin care Iisus Hristos se menţine prezent între noi şi în noi cu scop soteriologic. Fragmentarea confesională a pastorației prin Sfintele Taine poate fi în detrimentul prezenţei lui Hristos şi, implicit, în detrimentul propriei noastre mântuiri. Recrudescența protestantă şi neoprotestantă faţă de Sfintele Taine, de exemplu, trebuie înţeleasă, cel mult, ca o „mânie” împotriva unor oameni care s-au folosit de harurile dumnezeieşti în scopuri nedumnezeieşti. De asemenea, auto-suficienţa Bisericilor tradiţionale cu privire la Sfintele Taine trebuie înţeleasă cel mult ca o fidelitate de administrator faţă de bunurile care aparţin lui Dumnezeu; altfel, putem vorbi despre $o$ deposedare a lui Dumnezeu de realităţile care îi aparţin doar Lui.

Ecumenismul sacramental este un efect al atitudinii lui Dumnezeu, nu un scop al teologiei contemporane sau al teologilor contemporani. În acest sens în practica pastoral-misionară trebuie să se regăsească atitudinea lui Dumnezeu. Doar astfel ea este theoforică, logoforică şi pneumatoforică, adică, doar în acest caz este trinitarodoxologică. De aceea Sfintele taine și săvârșirea lor constituie elementul sine qua non prin care Dumnezeu îşi face viu şi lucrător cuvântul Sfintelor Scripturi în viaţa Bisericii precum şi în zidirea spirituală a membrelor Acesteia.

${ }^{16}$ În Germania, Mitropolia Ortodoxă Română pentru Europa Centrală și de Nord a fost recunoscută recent drept corporație publică. Despre aceasta, a se vedea studiul pr. prof. dr. Adrian Gabor, Contribuţii actuale ale Bisericii Ortodoxe Române privind integrarea în Uniunea Europeană, în vol. „Biserica Ortodoxă în Uniunea Europeană...”, ed. cit., p. 35 
Măreţia fiecărei confesiuni creştine în parte nu trebuie să constea dintr-o sinonimie a egoismului şi exclusivismului promovat de vechii sau noii evrei, iar Teologia Sacramentală și cea Pastorală nu permite acest lucru. Cele două coagulează spiritul de căutare a lui Dumnezeu din fiecare ființă umană, de împlinire a ei până la statura bărbatului desăvârşit, iar acest mod pastoral misionar are rostul să mărească împărăţia lui Hristos reprezentată în şi prin Biserică. Împreună moştenitori, un singur trup, parte la aceeaşi făgăduinţă sunt declaraţii dumnezeieşti care derivă din Taina lui Hristos Cel în Treime slăvit, şi trebuie să se regăsească în toate celelalte Sfinte Taine care mijlocesc şi împărtășesc, după necesități, harul koinoniei în vederea sfinţirii și a desăvârşirii individuale.

Din acest motiv, Sfintele Taine, săvârșirea lor, rămâne paradigma ecumenică prin excelență a comuniunii dintre Dumenzeu și creatura Sa, dintre Hristos și cei pentru care S-a jertfit, dintre Duhul Sfânt și toți cei care-l primesc prin exact aceste lucrări harice, îndumnezeitoare, care sunt Sfintele Taine.

\section{Bibliografie}

1. ANDRUTSOS Hr., Simbolica, Craiova, Edit. Centrului Mitropolitan al Olteniei, 1955.

2. BĂBUŞ, Emanoil, Ortodoxia naţiunilor în Europa Occidentală, în: „Biserica Ortodoxă în Uniunea Europeană. Contribuţii necesare la securitatea şi stabilitatea europeană”, Bucureşti, Edit. Universităţii din Bucureşti, 2006.

3. BUCHIU, Ştefan, Intrupare şi unitate, Bucureşti, Editura Libra, 1997.

4. CIOCAN, Pr. lect. univ. dr. Tudor Cosmin, Curs De Misiologie Şi Ecumenism, disponibil online la http://ctcresearch.ro/files/ Download/CURS\%20DE \%20misiologie\%202.2013.pdf.

5. EVDOKIMOV, Paul, Prezenţa Duhului Sfânt în Tradiţia Ortodoxă, Bucureşti, Edit. Anastasia, 1995. 
6. GAMBOȘ, Stelian, Biserica Ortodoxă în fața provocărilor lumii contemporane și rolul ei social-filantropic în societatea postmodernă, secularizată, disponibil la http://www. crestinortodox. ro/religie/biserica-ortodoxa-fataprovocarilorlumii-contemporane-124595.html.

7. JUSTINIAN, Patriarhul, Apostolat social, vol. V, 1948.

8. MOLDOVAN, Ilie, Pregătirea morală pentru primirea Sfintelor Taine, în rev. „Glasul Bisericii”, anul XXXVII (1978), nr. 3-4.

9. MUREŞAN, Radu Petre, Provocări şi perspective ale Bisericii Ortodoxe în Uniunea Europeană, în: „Biserica Ortodoxă în Uniunea Europeană. Contribuții necesare la securitatea şi stabilitatea europeană”, Bucureşti, Edit. Universităţii din Bucureşti, 2006.

10. PICIORUȘ, Dorin Octavian, Sfintele Taine ca resursă pentru ecumenism hristocentric și comuniune interconfesională, material disponibil la http://www.teologiepentruazi.ro/2012/09/08/ sfintele-taine-ca-resursapentru-ecumenism-hristocentric-sicomuniune-interconfesionala/.

11. PLĂMĂDEALĂ, Antonie, Biserica slujitoare, Bucureşti, 1972.

12. STĂNILOAE, Pr. Prof. Dr Dumitru, Teologia dogmatică ortodoxă, vol. 3, Bucureşti, Edit. I.B.M. B.O.R., 1997.

13. STĂNILOAE, Dumitru, Slujitori ai lui Dumnezeu, slujitori ai oamenilor, în rev. „Biserica Ortodoxă Română”, anul LXXXVIII (1970), nr. 3-4.

14. YANNARAS, Christos, Abecedar al credinţei, Bucureşti, Edit. Bizantină, 1996. 